\title{
Konstrukce měrného nástroje pro výzkum a modelování současného dospívajícího čtenáře ${ }^{1}$
}

\author{
The design of specific tools for research and modeling of contemporary teenage readers \\ Kateřina Homolová
}

\begin{abstract}
Abstrakt: Příspěvek se zaměřuje na užití smíšené metodologie při výzkumu (nejen) dětského čtenářství. Chce nabídnout reflexi př́stupů k poznání čtenářství dospívajících, a to nejen $\mathrm{v}$ systému základních statistických údajů, ale zejména $\mathrm{v}$ jeho rovině psychosociální. Na čtenáře je pohlíženo jako na sociální roli a na čtenářství jako na specifické chováni s individuálním významem a hodnotou. Psychosociální aspekty čtenářství dospívajících je možno vedle klasického dotazníku dále konkretizovat technikami psychometrie, a to sémantickým diferenciálem a Q-metodologií. Ty umožňují odhalit individuální psychologický význam nejen pojmů čteni, čtenářství, čtenář a bytí čtenářem, ale také jejich vztah $\mathrm{k}$ pojmům mimo čtenářský sémantický prostor. Stanoveni vhodných Q-typů a jejich distribuce přináší možnost poznat hodnotu, kterou současní dospívající čtenářství přisuzuji. Autorka využívá svých dosavadních výzkumných poznatků a směřuje $\mathrm{k}$ vytvoření širokospektrého měrného nástroje. Jím získané výsledky bude pak možno využít k aktualizaci stávajícího čtenářského modelu.
\end{abstract}

Klíčová slova: smíšený výzkumný design, čtenářství dospívajících, sociální role čtenář, psychosociální aspekty, diagnostika, dotazník, sémantický diferenciál, Q-metodologie

\begin{abstract}
The paper focuses on the use of mixed methodologies in research (not only) children's reading. It wants to offer a reflection on approaches to the adolescent readership, not only in the system of basic statistical data, but especially in its psychosocial level. The reader is viewed as a social role and the readership as the specific behavior with individual meaning and value. Psychosocial aspects of adolescent readership is possible to recognize with the traditional questionnaires, but also using the specific psychometric techniques semantic differential and Q-methodology. They allow us to discover not only the importance of individual psychological concepts of reading, readership, reader's role, and being a reader, but also their relationship to the notions out of reader's semantic space. Determination of appropriate Q-types and their distribution gives the opportunity to learn the value that ascribes contemporary teenagers to a readership. The author uses her experiences from previous researches to create a broad-spectrum specific research tools which could be used to update existing reader's model.
\end{abstract}

Keywords: mixed research design, adolescent readership, reader's role, psychosocial aspects, diagnostics, questionnaire, semantic differential, Q-methodology

\footnotetext{
${ }^{1}$ Tento př́spěvek vznikl za podpory grantu SGS SU 3/2011 Konstrukce měrného nástroje pro výzkum a modelování současného dospivajicího čtenáré.
} 


\section{Př́stupy k diagnostice klíčových aspektů dětského čtenářství}

Odborné diskuse nad metodologickým uchopením sond do struktury dětského čtenářství nejsou v našem prostředí př́liš časté. Máme za sebou období, kdy čtenáře určovalo primárně číslo. Kvantitativní údaje o počtu přečtených titulů za časovou jednotku a o počtu knih vypůjčených z knihovny či umístěných v domácí knihovničce na dlouhou dobu stačily pro určení kategorie čtenár a poněkud pejorativně (a pedagogicky nevhodně) chápaného protipólu nečtenár. Poznáváme tak „množstevní aspekty dětského čtenářství. Takto získaná data jsou využitelná jen v omezené míre, nereflektována zůstává jejich motivace.

S rozvojem zájmu o psychologii čtenáře začínají se domácí výzkumníci orientovat na recepční dispozice čtenáře. Tento trend má u nás i ve světě silnou tradici, opírá se hlavně o psychologii osobnosti a o sociologii (Lederbuchová, 2004, s. 29). Na tomto základě staví současná teorie čtenářství a další metodologicky divergentní směřování. Číselné vyjádření čtenářství není apriori popíráno, avšak slouží jako výchozí platforma pro další aplikace a analýzy.

Dětské čtenářství ve svých psychosociálních aspektech je materiálem pro smíšené výzkumné strategie. $\mathrm{V}$ tomto př́padě je nanejvýš rozumné sbírat a analyzovat data pomocí několika metod, jejichž kombinace vede k zesílení př́nosu každé z nich. Osvědčuje se výzkum na základě smíšeného modelu, kdy využíváme jak kvantitativní, tak kvalitativní postupy uvnitř jednotlivých fází výzkumného procesu. Mixujeme jak typy výzkumných otázek, tak př́istupy ke sběru dat (např́íklad v dotazníku kombinací uzavřených i otevřených otázek, užitím technik psychometrie apod.) či prŕstupy k jejich analýze (Hendl, 2005).

\section{2 Čtenář určený číslem}

Výchozí etapou komplexního výzkumu zaměřeného na současného dospívajícího čtenáře je poznání, popis a kategorizace kvantity jeho četby. Dotazníkovým šetřením klasického typu lze ze získaných četností zjistit, jak souvisí určité rysy čtenářského chování respondenta $\mathrm{s}$ jeho čtenářskou kompetencí (náklonnost $\mathrm{k}$ četbě a uspokojení z ní, soustředěná samostatná četba, potřeba hovořit o přečteném, četba časopisů versus četba knih apod.). Považujeme za stále relevantní a účelné sledovat i takové tradičně vymezené aspekty čtenářství, jakými jsou počet přečtených knih za určitý čas, frekvence četby atp., jelikož ve struktuře čtenářských dispozic dospívajících každá z těchto aktivit ovlivňuje všechny další.

Sporné otázky kolem konstrukce dotazníku pro zjištování subjektivního významu čtenářství u dospívajících se soustřed'ují do dvou skupin. První tvoří požadavky na formální stránku sestavování dotazníkových položek. Vzhledem k věku respondentů (10-15 let) je třeba volit adekvátní slovník a styl podání. Záležitost na první pohled samozřejmá není vždy respektována a bývá z větší části determinována osobností výzkumníka. Prioritním je vždy hledisko respondenta, nebot' on musí porozumět, aby mohl odpovědět - vyjádřit subjektivní realitu ve smyslu výzkumného záměru.

Druhá skupina problémů s konstrukcí dotazníku je spojena s obsahem jednotlivých položek. Chceme zjišt'ovat a hodnotit osobní čtenářské naladění pubescenta, což automaticky zvyšuje míru jeho snahy po stylizaci. Toto je nutno předpokládat a formulovat otázky či úkoly tak, aby vyznívaly co možná nejvíce věcně, jako prosté zjišt'ování stavu. Vyhýbáme se proto jakémukoli náznaku hodnocení v otázkách, není žádoucí emocionální zabarvení položek z pozice tazatele. Naopak předjímáme silnou citovou angažovanost pubescentů pro určité činnosti a určitá fakta a $z$ tohoto zjištění (podpořeného poznatky z vývojové a sociální psychologie dospívajících) vycházíme ve formulaci položek týkajících se zvláště těkavých aspektů jejich čtenářského chování. 
Dotazník je i dnes vhodnou zástupnou metodu dlouhodobého pozorování. Zprostředkovává na malém prostoru velkou sumu dobře zpracovatelných nominálních, ordinálních, intervalových i poměrových dat, která navíc mohou již na této úrovni upozornit i na sebehodnocení čtenáre (Homolová, 2008, s. 121-123). Čtenářství určené četností dílčích projevů čtenářského chování respondenta je možno vyjádřit deskriptivními statistickými ukazateli a podrobit řadě testů významnosti.

\section{3 Čtenář ve významech pojmů}

Zkoumání a diagnostika dospívajícího čtenáře s sebou nese také otázku týkající se příčin a motivací kvantitativně získaných dat. Víme-li, zda dospívající čte, nebo nečte, nevíme však ještě zdaleka všechno o jeho uvažování o čtenářství jako společenském fenoménu. Chceme proto $\mathrm{v}$ našem výzkumném designu vymezit i místo a roli čtenářství v životě a sémantickém prostoru současných dospívajících.

Za tímto účelem se nejvhodnějším jeví užití vybraných technik psychometrie. Zastrukturování pojmu čtenář podle jeho subjektivního významu pro dospívajícího respondenta umožňuje vyhodnotit metoda sémantického diferenciálu (zástupně by bylo možno použít tzv. afektivního škálování). Společně s Chráskou (2007) vycházíme z předpokladu, že každý pojem má vedle společného kulturního významu (socializovaného), také vedlejší konotativní významy (individuální).

Vzorek pojmů musí být vybrán tak, aby reprezentoval některé části sémantického prostoru zkoumaného jevu. To je dle Kerlingera (1972, s. 550) „nejdůležitější práce“. Při měření sociálních postojů, jimiž postoje $\mathrm{k}$ fenoménu čtenářství do jisté míry jsou, je nutno volit pojmy zvláště uvážlivě. Pro námi zkoumaný fenomén čtenářství dospívajících jsme v dříve realizovaných výzkumech (Homolová, 2008) volili vyšší počet pojmů, které se vztahovaly nejen $\mathrm{k}$ bytí čtenářem, ale také $\mathrm{k}$ mimočtenářské realitě. $\mathrm{V}$ současnosti se jako funkční jeví výrazná redukce pojmů směrem $\mathrm{k}$ osobnosti čtenáře. Ve formuláři nadále zůstávají pojmy čtenářství, kniha, čtení a především čtenář, bytí čtenářem a já-čtenářr.

Bipolární škály volíme podle povahy posuzovaných pojmů, pro získání relevantních dat vždy ale výběrem z původního seznamu 50 škál C. Osgooda (Chráska, 2007, s. 225-226). Přesto je na místě faktorovou strukturu škál ověřovat faktorovou analýzou. V další fázi vývoje stabilního formuláře sémantického diferenciálu pro výzkum současného dospívajícího čtenáře budou zohledněny výsledky předvýzkumu a adekvátně upraveny škály pro posuzování pojmů.

To umožňuje efektivnější kvantitativní zacházení s daty (výpočet lineární distance, tvorba Dmatic) pro jejich účelnější kvalitativní interpretaci.

\section{4 Čtenář v systému norem a hodnot}

Současného dospívajícího čtenáře charakterizuje - vedle četností projevů čtenářského chování a vedle čtenářských pojmů umístěných významně blízko centru jeho obecného sémantického prostoru - rovněž tendence přisuzovat čtenářství hodnotu a odrážet v něm své osobní normy. $\mathrm{K}$ tomu je vhodné využít Q-metodologii, resp. Q-techniku coby zařazování objektů do pořadí (a přiřazování čísel podmnožinám objekti̊ pro statistické účely).

Využití Q-techniky vhodně apeluje na mnohdy velmi vyhraněný postoj dospívajících jak k nabízeným faktům, tak ke zvolenému kritériu jejich hodnocení. Adekvátně zvolené Q-typy verbální povahy obsahují výpovědi o čtenářství, osobě čtenáře, vlastním čtení včetně názorů a postojů ke knihám. Zadáván je požadavek kvazinormální distribuce. Zajištujeme tak nutnou 
podmínku pro využití korelačního koeficientu při srovnání postojů různých skupin respondentů (chlapců a dívek, mladších a starších dospívajících).

Je-li je našim cílem vytvoření modelu současného dospívajícího čtenáře, pro další práci s daty získanými Q-trríděním volíme techniku faktorové analýzy, z níž vzejdou typy třídění zkoumaných osob - typy čtenářů.

Využití Q-techniky je provázeno také určitými konstrukčními nevýhodami. Jedná se zejména o stanovení počtu Q-typů pro jednotlivé hromádky. Doporučován je počet 60-120 výpovědí, autorka má však dobré zkušenosti také se 40 výroky a rovněž i s miniaturním tříděním 10 Qtypů. Určující pro tuto redukci bylo časové hledisko a relativní náročnost techniky pro respondenta. Vlastní Q-typy je nutno volit tak, aby se v rámci určeného počtu dotýkaly co možná nejvíce aspektů sledovaného fenoménu čtenářství a byly srozumitelné. Kerlinger (1972, s. 578n) poukazuje na další možná rizika spojená s aplikací Q v pedagogickém výzkumu. Poukazuje se zde však více na problémy s vyhodnocováním Q-třídění statistickými metodami.

V každém případě je užití Q-techniky dobrým prostředkem simultánní triangulace (postup, při němž se užívají kvantitativní i kvalitativní metody ve stejném okamžiku). Lze říci, že zkoumaný jev je pak charakterizován dostatečně spolehlivými informacemi a jeho obraz je možno považovat za objektivní.

Popsaná smíšená metodologická strategie vychází z vědomí nutnosti nahlížet na čtenářství jako na strukturu, jejíž složky tvoří zájmy a potřeby čtenáře, které se v různých vztazích aktualizují v procesu četby i v celkovém čtenářském chování pubescenta, v jeho čtenářském postoji. Na četbu a čtenářství je tedy možné pohlížet na jedné straně analyticky jako na jednotlivé čtenářské aktivity a jejich vztahy. Na druhé straně ale vědomí vztahů brání hodnotit a interpretovat tyto projevy čtenářství izolovaně.

Konstrukce komplexního měrného nástroje pro výzkum dospívajícího čtenáře je stěžejní záležitostí celého výzkumného designu. Pouze relevantní zjištovací metody mohou přinést reálně použitelná data.

\section{5 Čtenář modelový a modelovaný}

Výše uvedeným postupem poznaný a pochopený profil současného dospívajícího čtenáře budeme $\mathrm{v}$ dalších etapách výzkumného záměru srovnávat s predikčním modelem dětského čtenáře (Smetáček, Jonák, \& Voznička, 1985).

Predikční model obecně pracuje se známými fakty, s naměřenými daty a jejich interpretacemi a na tomto základě odhaduje budoucí hodnoty skutečného průběhu. Stávající a již čtvrt století existující čtenářský model Smetáčkova kolektivu je stále aktuální ve způsobu uchopení proměnlivé struktury potřeb, zájmů a dalších charakteristik dětského, resp. dospívajícího čtenáře. Zjišt'ujeme však, že klima, v němž se toto čtenářství formuje dnes, žádá proměnu soustavy položek, které jsou k predikčnímu modelu zjišt'ovány.

$\mathrm{V}$ rámci úvah o změně př́stupu k modelování dospívajícího čtenáře akcentujeme zejména redukci sociálně-osobnostních charakteristik, nebot' např. na školní úspěšnost lze úspěšně usuzovat z poznání vybraných postojových komponent. Stejně tak se domníváme, že ani detailní popis množství statických čtenářských charakteristik (velikost domácí knihovny, zdroje získávání knih apod.) není pro efektivní vytvoření představy o síti vazeb čtenářství současných dospívajících důležitým faktorem. 
Psychosociální zkoumání dětského čtenářství je dnes funkční cestou k měření a pochopení specifických vývojových posunů, strukturních proměn čtenářských postojů a aktivit, jejich vlastností a vzájemných vztahů. Smíšený výzkumný design tyto potřeby cele naplňuje.

\section{Literatura}

Hendl, J. (2005). Kvalitativni výzkum. Praha: Portál.

Homolová, K. (2008). Pedagogicko-didaktické a psychosociální aspekty pubescentního čtenářství.

Ostrava: Ostravská univerzita.

Chráska, M. (2007). Metody pedagogického výzkumu. Praha: Grada.

Kerlinger, F. N. (1972). Základy výzkumu chování. Praha: Academia.

Lederbuchová, L. (2004). Ditě a kniha. Plzeň: Aleš Čeněk.

Smetáček, V., Jonák, Z., \& Voznička, V. (1985). Predikční model dětského čtenáře. Čtenář, 37(7).

\section{Kontakt}

PhDr. Kateřina Homolová, Ph.D.

Slezská univerzita v Opavě

Filozoficko-př́rodovědecká fakulta v Opavě, Ústav bohemistiky a knihovnictví

Masarykova 37, 74601 Opava

e-mail: katerina.homolova@fpf.slu.cz

\section{Bibliografické údaje}

Homolová, K. (2011). Konstrukce měrného nástroje pro výzkum a modelování současného dospívajícího čtenáře. In T. Janík, P. Knecht, \& S. Šebestová (Eds.), Smíšený design v pedagogickém výzkumu: Sborník př̀spěvků z 19. výroční konference České asociace pedagogického výzkumu (s. 175179). Brno: Masarykova univerzita.

Dostupné z: http://www.ped.muni.cz/capv2011/sbornikprispevku/homolova.pdf

doi: 10.5817/PdF.P210-CAPV-2012-12 